\title{
Study on the Durability of Road Concrete with Blast Furnace Slag Affected by the Corrosion Initiated by Chloride
}

\author{
Liliana Maria Nicula, ${ }^{1}$ Ofelia Corbu $\mathbb{D}^{1,2,3}$ Mihai Iliescu, ${ }^{1}$ Andrei Victor Sandu $\left(\mathbb{D},{ }^{4,5}\right.$ \\ and Andreea Hegyi ${ }^{6}$ \\ ${ }^{1}$ Technical University of Cluj-Napoca, Faculty of Civil Engineering, 28, Memorandumului Street, 400114 Cluj-Napoca, Romania \\ ${ }^{2}$ Research Institute for Construction Equipment and Technology, ICECON S.A., Pantelimon Road 266, 2nd District, CP 3-33, \\ 021652 Bucharest, Romania \\ ${ }^{3}$ Center of Excellence Geopolymer \& Green Technology (CEGeoGTech), School of Materials Engineering, \\ Universiti Malaysia Perlis, 01000 Kangar, Perlis, Malaysia \\ "Gheorghe Asachi" Technical University of Iaşi, Faculty of Materials Science and Engineering, Dimitrie Mangeron Street 67, \\ 700050 Iaşi, Romania \\ ${ }^{5}$ Romanian Inventors Forum, Sf. P. Movila 3, 700089 Iaşi, Romania \\ ${ }^{6}$ National Institute for Research and Development in Construction, \\ Urban Planning and Sustainable Spatial Development "URBAN-INCERC," Cluj-Napoca Branch, Calea Floresti Street 117, \\ Cluj-Napoca, Romania
}

Correspondence should be addressed to Ofelia Corbu; ofelia.corbu@staff.utcluj.ro and Andrei Victor Sandu; sav@tuiasi.ro

Received 21 September 2020; Revised 22 December 2020; Accepted 31 December 2020; Published 15 January 2021

Academic Editor: Yingchun Li

Copyright (c) 2021 Liliana Maria Nicula et al. This is an open access article distributed under the Creative Commons Attribution License, which permits unrestricted use, distribution, and reproduction in any medium, provided the original work is properly cited.

\begin{abstract}
In order to assess the resistance of the road concrete to the penetration of the chloride ions, we used the rapid test RCPT in compliance with ASTM C1202. But, in order to increase the reliability of the rapid test of assessing the resistance of chloride ions' permeability through measurements of the electrical conductivity, after finishing the RCPT test, we have also measured the depth of the chloride front migrating in the concrete. Road concrete mixtures were prepared in which blast furnace slag (GGBS) was incorporated as a binder and blast furnace slag (ABS) as crushed slag aggregate to the size of $0 / 4 \mathrm{~mm}$. The effect of the blast furnace slag on the RCPT results was investigated and correlated with porosity trends, carbonatation layer depth, and with the compression strength values, by comparison with the level of results obtained on concrete mixtures made with conventional materials. The measurement of the migrated chlorine front in the concrete together with the determined physical and mechanical characteristics confirms the efficiency of the blast furnace slag incorporated in the concrete and supports the reliability of the rapid penetration test of chlorine ions RCPT using the procedure from ASTM C 1202.
\end{abstract}

\section{Introduction}

An important feature that affects the durability of road concrete is the corrosion of the reinforcements embedded in the concrete. Corrosion degradation attributed to the reinforcement in the concrete structure was estimated to represent $25 \%$ of the causes that influence the durability of concrete $[1,2]$. In the case of road pavements, the steel reinforcements are incorporated either at the longitudinal contact joints or at the expansion joints or on the entire surface of the slabs in the case of continuously reinforced road pavements. Usually, the concrete reinforcement is protected by an inert and dense layer, of nanometric thickness, of iron oxide, with a passive role, which surrounds the steel reinforcement, being supported by the alkalinity of the cement paste and by the thickness of the covering layer. But chloride ions can destroy the passive layer surrounding the steel reinforcement by increasing the 
chloride concentration, activating chemical corrosion $[1,3]$.

When the passivating protective layer of the reinforcement is pierced by chloride ions, spot corrosion (pitting) is initiated. Local craters are formed, whose depth advances and which are partially filled with an unstable corrosion product of iron, ferrous oxide, friable, which makes it difficult to assess the degree of corrosion. At the same time, the corrosion products of iron with a volume much higher than the volume of iron (expansion factor of 2-10 times) will induce local stresses in the surrounding cement matrix, thus initiating cracks that will allow the penetration of chloride ions more easily and the advancing of the corrosion [4]. In addition to the presence of a significant amount of chloride ions at the reinforcement level, the destruction of the passive layer also occurs due to carbonation which reduces the $\mathrm{pH}$ of the water in the concrete pores to the unprotective level [5-12]. The carbonatation is a chemical reaction of portlandite $\mathrm{Ca}(\mathrm{OH})_{2}$ and hydrated calcium silicate $(\mathrm{CSH})$ with carbon dioxide $\left(\mathrm{CO}_{2}\right)$ present in air or water and forms calcium carbonate $\left(\mathrm{CaCO}_{3}\right)$ and water $\left(\mathrm{H}_{2} \mathrm{O}\right)$. At a certain moisture content, the carbon dioxide $\left(\mathrm{CO}_{2}\right)$ enters the pores of the concrete through gaseous diffusion. Normally, the high natural alkalinity conditions present inside the concrete protect the reinforcement against corrosion reactions. However, carbonatation lowers the $\mathrm{pH}$ value from typical values $(12 \div 13)$ to less than 9 of the pore solution and destroys the passivity of the built-in reinforcement bars, triggering the corrosion process [13-16]. For permeable concretes, the increase of $\mathrm{CO}_{2}$ concentrations in the external environment increases the carbonatation rate [17], but a compact cement matrix prevents the diffusion of carbon dioxide [18] and does not endanger the decrease of the compressive strength of the concrete [19]. Tuutti has developed a model for predicting the life of steel reinforcement, according to which the corrosion process distinguishes two stages: the first stage of corrosion initiation and the second stage of corrosion propagation. From the onset of the corrosion the duration until the degradation is influenced by relative humidity, ambient temperature, and oxygen level in the air [20,21]. The period of onset of corrosion will not immediately affect the performance of the reinforcement, but the period of corrosion propagation must be taken into account because the performance of the entire reinforced concrete element can be significantly affected $[21,22]$. The propagation of corrosion leads to accelerated corrosion, which is manifested by rust staining, cracking of the reinforcement coating, longitudinal cracking in the structure, chipping, and delamination of the reinforcement coating $[20,23]$. The research studies show that there are different types of calcium nitrite-based additives for concretes that generate chemical and physical inhibition mechanisms to keep the layer around the reinforcement inert $[1,24,25]$. Using the half-cell-potential method (HCP) which quantifies the progression of corrosion activity by the measured potential difference between the tested sample and a reference electrode, Pei et al. showed that an increase in the $w / c$ ratio in the mortar from 0.5 to 0.7 led to a major decrease in the time until the reinforcement corrosion started.
However, the literature also indicates that this method (HCP) does not assess the actual corrosion rate, but a comparative evolution with a control, which suggests other more advanced techniques such as determining the resistance by linear polarization (LPR) [26]. Another way of reducing the risk of corrosion of concrete reinforcement can also be obtained by embedding optimal dosages of additional cementitious materials (SCM), such as fly ash, blast furnace slag, and ultrafine silica [27-32]. It is known that ultrafine silica provides the highest protection of steel reinforcement due to the small particle size (approximately $0.1 \mu \mathrm{m}$ ), which produces a pozzolanic reaction with portlandite $(\mathrm{CH})$ forming a good bond of the interfacial transition zone (ITZ) between the cement paste and the aggregate $[1,33]$.

In 1970, the Federal Highway Administration (FHWA) was concerned with discovering a rapid method of assessing the penetration of chloride ions into the reinforcement coating due to the need to use thawing salts in road coverings. The results from the methods existing at that time were specific to the evaluation of the permeability of concrete to water and air, without presenting a correlation with the methods for assessing the diffusion of chloride ions [1,34]. In 1981, a final version was developed used in the laboratory to determine the chloride penetrability class of concrete, and, in 1991, the RCPT test was documented in ASTM C1202 [35]. The concept of the RCPT method, in compliance with ASTM C1202, is based on the mobility of chloride ions forced to enter the concrete by inducing an external stress applied directly to the concrete surface. The migration of chloride through concrete is a slow process, but the researchers found that when an electric current is applied to a concrete test tube, the speed at which chlorides migrated into concrete was accelerated, which is why the test is currently commonly used [1]. However, the RCPT test is not recommended for use in concrete mixtures that include dispersed reinforcing fibers or corrosion inhibitors such as calcium nitrites, as they influence the electrical conductivity and artificially increased results are obtained. The reliability of the RCPT test method has been criticized for various shortcomings, also in the use of additional materials with cementitious characteristics such as ultrafine silica $[1,36]$. Currently, there is still controversy regarding the influence of heat generated by the electric current applied on the results, respectively, on the migration of chloride ions, due to the fact that it cannot identify only them [37]. Therefore, to minimize the effect of temperature on electrical conductivity, previous studies have suggested additional RCPT measurements after short periods of 1 minute and 30 minutes, as it has been observed that no large temperature differences are recorded during this interval. Multiplying the measurements at 30-minute intervals allows extrapolated calculation of passing charges and resistivity. The resistivity of the concrete calculated from the RCPT test can estimate the duration of the corrosion propagation stage until the concrete yields [20,38-40]. Feliu et al. [41, 42] made a correlation between the measured resistivity of the concrete and the corrosion rate at the level of the embedded reinforcement, these evolving inversely proportionally. 
This was also confirmed by Glass et al. [41, 43], which showed that the resistivity of mortar is dependent on the relative humidity of the environment, while López et al. $[41,44]$ showed that the volume of the concrete pores influences its resistivity and, therefore, the corrosion rate of the reinforcement. Another parameter for assessing the penetration of chloride ions is the diffusion coefficient of chloride ions, which can be evaluated by the NT Build 492 test [45], a test method used in Finland to determine the migration of chloride ions in an unstable state. This method is an alternative to ASTM C1202, differing in exposure time (24 to 96 hours) and applied voltage $(30 \mathrm{~V})$. The diffusion coefficient results from the values of chloride penetration, sample thickness, exposure time, voltage, and average sample temperature [46]. The diffusion of chloride ions from the concrete determines the stage of corrosion initiation while the resistivity of the concrete shows the speed of corrosion propagation [1,47]. The study by Bassuoni et al. showed that the determination of the migration coefficient of chloride ions can eliminate the uncertainties in the rapid RCPT test of electrical conductivity. Chloride migration coefficients are sensitive to the physical characteristics of the pore structure, and the passing charges are mainly influenced by the ionic concentration of the pore solution. The materials incorporated in concrete, such as ultrafine silica and CNI calcium nitrite corrosion inhibitors, can influence the chemical elements of the pore solution, so the RCPT rapid test method proved to be insufficient and was supplemented with the calorimetric method [1]. McGrath and Hooton [48] studied the influence of the potential difference on the diffusion coefficients of concrete chloride. The diffusion coefficients of chlorine ions in the unstable state were calculated by applying the Nernst-Planck equation, using the data from the accelerated chloride penetration tests under the conditions of applying a potential difference between 6 and 30 volts. The conclusions showed that the error of the results increased as the nominal potential decreased. Soleymani and Mohamed [49] conducted a laboratory study to estimate the corrosion of steel reinforcement for two types of concrete, ordinary and high performance. The results indicated that Tafel interpretation (TP), linear polarization resistance (LPR), semicellular potential measurement (HCP), and determination of chloride content by other methods obtained the same level of corrosion activity in only $24 \%$ of the samples. The study shows the need to combine these methods in order to increase the accuracy of the assessment of the degree of the concrete reinforcement corrosion. Coşa et al. tested by two methods the penetration depth of chlorine ions in the self-compacting concrete made with the addition of fly ash or limestone filler. The study shows that using the colorimetric method with silver nitrate solution $\left(\mathrm{AgNO}_{3}\right)$ results were obtained for the depth of chloride penetration, but additionally using the scanning electron microscopy (SEM) method, the concrete chloride concentration was determined, and the results for the penetration depth of chlorine ions were more precise. The advantages of using electron microscopy have proven to be remarkable, but not in the sense of undermining the efficiency and practicability of the colorimetric method [50]. Yeau and collaborators showed that the concrete with substitution of $40 \%$ blast furnace slag (GGBS) relative to the cement mass and even above this level showed higher corrosion resistance compared to cement concrete without (GGBS), after 56 days of immersion in water [27]. Sancharoen and Uomoto [51] obtained higher corrosion resistance of concrete reinforcement with (GGBS) compared to Portland cement concrete. However, with the cyclic and simultaneous exposure of concrete with (GGBS) to chlorine ion corrosion and carbonation, the corrosion resistance decreased compared with conventional concrete, so it was suggested that their durability be carefully analysed. Noushini et al. [52] studied the diffusion resistance of chloride on lowcalcium fly-ash-based geopolymer concrete at different temperatures and hardening times. For this concrete, the highest chloride diffusion coefficient was obtained by heat treatment at $60^{\circ} \mathrm{C}$ for 24 hours. The chloride diffusion coefficient decreased with the increase of the tartar temperature from $75^{\circ} \mathrm{C}$ to $90^{\circ} \mathrm{C}$, but the values recorded were higher compared to concrete based on (OPC). Another observation of research shows that conventional concrete has a higher chloride binding capacity compared to geopolymer concrete. Most physically bound chlorides did not contribute to the corrosion of steel reinforcements, but were attacked by free chloride ions from concrete.

The purpose of this work was to analyse the corrosion resistance of the reinforcement embedded in the road concrete prepared with blast furnace slag, started as a result of the penetration of chloride ions. The reliability of the rapid chloride ion penetration test, RCPT with ASTM C 1202, was also evaluated by supplementing the current method with the colorimetric method, aiming to evaluate the depth of the front and the migration coefficients of chloride ions. At the same time, the content of permeable pores was evaluated, which was a useful index for correlating with the migration coefficients of chlorine ions in concrete. In order to strengthen the results obtained by the rapid RCPT test, the concordance between the compressive strengths and the resistivity of the concrete to the penetration of chlorine ions were also analysed. The results of this study will complement the mechanical characteristics of concrete obtained by the authors of previous investigations. Based on sustainability criteria, the present study aims at selecting the optimal proportions of locally sourced blast furnace slag, incorporated in the composition of road concrete. This paper highlights both granulated and ground blast furnace slag (GGBS) and crushed aggregates (ABS) obtained from ungranulated blast furnace slag. The controlled application of blast furnace slag in the composition of road concrete would be a start at the local level, helping to reduce the need for cement in concrete production, respectively, reducing $\mathrm{CO}_{2}$ emissions globally. This reduction is necessary taking into account statistics showing that cement production is responsible for around $7.4 \%$ of global carbon dioxide emissions [53]. Also, the concrete in this study would contribute to the reduction of the consumption of aggregates from natural reserves, estimated 
worldwide at a consumption of over 20.000 million tons/ year $[54,55]$.

\section{Materials and Methods}

2.1. Materials. CEM I 42,5R cement, according to EN 197-1: 2011 [56], and granular blast furnace slag from local sources were used as binder, having characteristics in compliance with the limits of standard EN 15167-1:2007 [57]. Before being placed in concrete, the granulated blast furnace slag was mechanically ground to a granulation of less than $63 \mu \mathrm{m}$, a size that supports its activity index [58-60]. The value of the specific surface of the cement was $4385 \mathrm{~cm}^{2} / \mathrm{g}$, with a specific weight of $3.00 \mathrm{~g} / \mathrm{cm}^{3}$, and that of the ground slag of $3775 \mathrm{~cm}^{2} / \mathrm{g}$, with a specific weight of $2.77 \mathrm{~g} / \mathrm{cm}^{3}$; these characteristics were determined in the laboratory of the Technical University of Cluj-Napoca. The ground and crushed slag had the sum of calcium, magnesium, and silicon oxides of $84.05 \%$ and a 28 -day activity index of $74.97 \%$, above the level of 70\% in compliance with EN 15167-1 : 2007. The content of chloride within the granulated blast furnace slag (GGBS) was $0.004 \%$, below the limit of $0.1 \%$ established in compliance with EN 15167-1:2007. The artificial aggregate from ungranulated blast furnace slag (ABS) is the result of a byproduct of the steel industry in Galati and has replaced in various proportions the natural aggregate with a grain size of $0 / 4 \mathrm{~mm}$.

The mineral phases of granulated (GGBS) and nongranulated (ABS) blast furnace slag were evaluated using $\mathrm{X}$-ray diffraction (XRD) and polarized light optical microscopy methods. The X-ray diffraction (XRD) investigations were performed with the equipment from the laboratory of the Department of Geology of Babeş-Bolyai University of Cluj-Napoca, using a Bruker D8 Advance diffractometer with $\mathrm{Cu} \mathrm{K} \alpha$ radiation $(\lambda=1.541874 \AA)$, Fe $0.01 \mathrm{~mm}$ filter, and a one-dimensional LynxEye detector. The microscopic images were taken using a Nikon Optiphot T2-Pol microscope with polarized light.

In granulated blast furnace slag (GGBS), the main mineral phase identified is merwinite, followed by magnesian gehlenite and carbon. Additionally, the glass appears in the amorphous phase (Figures 1 and 2). In the crushed aggregates from ungranulated blast furnace slag (ABS), the X-ray diffraction spectrum indicated as the main phase magnesian gehlenite and subordinate clinoferrosilite and aluminum silicate (Figures 3 and 4). From the results of the XRD measurements, the amorphous phase was estimated at $80 \%$ for granulated slag (GGBS) and at 100\% for nongranulated slag (ABS) in the crystalline phase. The proportions of aggregates used were $32 \%$ natural sand (size $0 / 4 \mathrm{~mm}$ ) and $68 \%$ coarse aggregate, of which the $8 / 4 \mathrm{~mm}$ sort was crushed river gravel and the $8 / 16 \mathrm{~mm}$ and $16 / 25 \mathrm{~mm}$ sorts were crushed chippings from the quarry. For the selection of the aggregates used and the particle size curve of the total mixture of aggregates, the conditions of the national standard NE 014 : 2002 were taken into account [61], and the physical and mechanical properties were in compliance with EN 12620:2003 and EN $12620+\mathrm{A} 1: 2008$ [62]. MasterGlenium SKY 527 superplasticizer additive and Master Air 9060 air entraining additive, produced by Badische Anilin und Soda Fabrik (BASF), were used in the preparation. The preparation water, in compliance with EN 1008:2003 [63], was taken from the supply system of the city of Cluj-Napoca.

\subsection{Preparing the Road Concrete Mixtures. In standardized} European models, there are no predictions of the service life of reinforced concrete structures exposed to corrosion caused by chloride attack. Also, the type of cement is not considered as a parameter in the evaluation for chlorideinitiated corrosion. However, Jan Bijen proposes some limits for concrete cement with blast furnace slag: a maximum corrosion rate of $5 \mu \mathrm{m} \mathrm{Fe} / y e a r$ for any point in the reinforcement, a chloride content of up to $2 \%$ of the mass of the slag cement, a $w / c$ ratio of 0.45 which together with the reinforcement coating, will not endanger the performance of the structure [22]. The design parameters of the road concretes in this experiment followed the minimum requirements for exposure class XD3 (exposure to corrosion $D$ due to chlorides of nonmarine origin, alternating moisturedrying, level 3 , in compliance to $[64,65])$. Thus, the max $w / c$ ratio (0.45), minimum strength class $\mathrm{C} 35 / 45$, and minimum cement dosage $320 \mathrm{~kg} / \mathrm{m}^{3}$ are provided. In the general study related to the durability of road concretes with blast furnace slag, two series of concretes with the same amount of (GGBS) and the same proportions of crushed aggregates from blast furnace slag (ABS) were poured. This study is part of the second batch series and comprises five compositions, coded S 360, S 414, S 54/20, S 54/40, and S 54/60, having the quantities of raw materials used according to Table 1 . The first two control mixtures were made with Portland cement and natural aggregates, and in the next three mixtures, we used granulated and grounded blast furnace slag under $63 \mu \mathrm{m}$ (GGBS) and aggregates from air-cooled crushed blast furnace slag (ABS) at the dimension of $0 / 4 \mathrm{~mm}$ in different proportions:

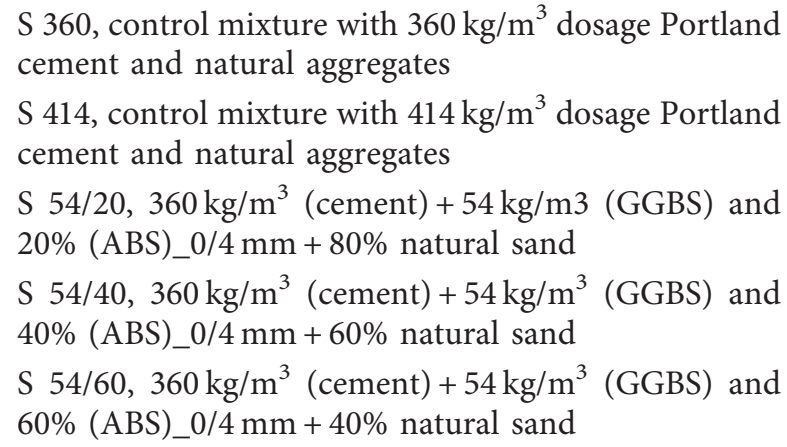

The water content and additives were adjusted in the second series of casting so as to ensure a consistency of at least $30 \mathrm{~mm}$, in compliance with NE 014:2002 [61]. Due to a water adjustment error in the preparation of the S 360 mixture, the $w / b$ ratio limit of 0.45 was exceeded.

The tests, trials, and analysis of the results were continued for the mixture of S 360 but for the compositions with built-in blast furnace slag only those obtained from the control mixture S 414 were considered as reference results. 


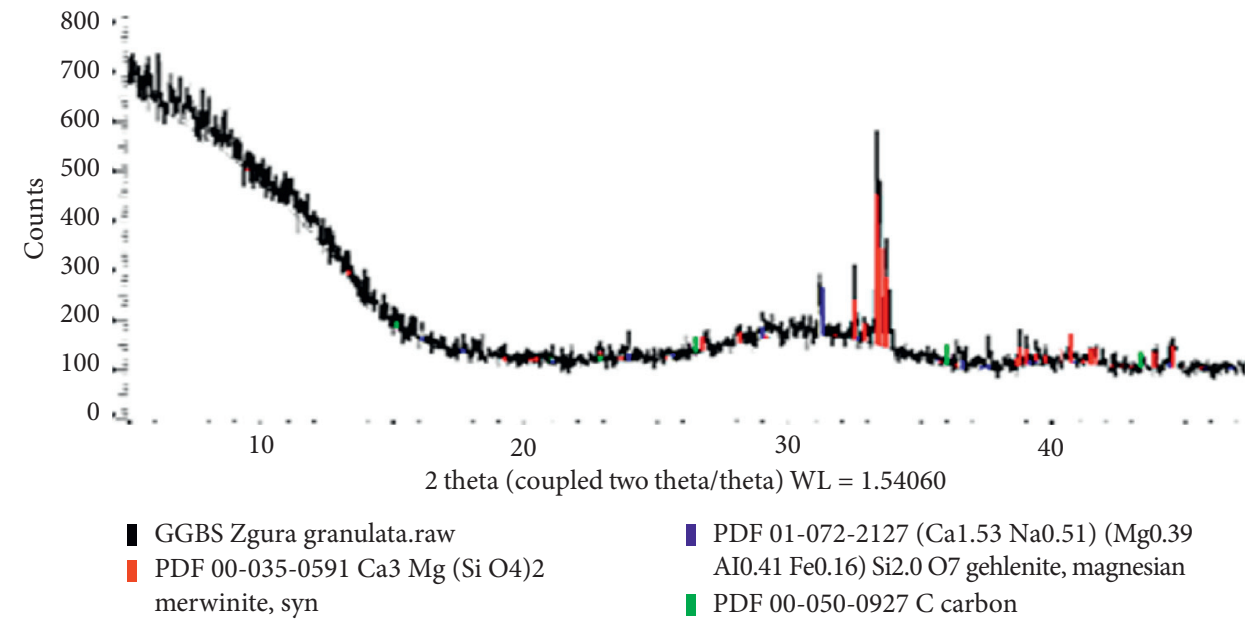

FIGURE 1: X-ray diffraction spectrum for GGBS with characteristic lines for magnesian gehlenite, merwinite, and carbon.

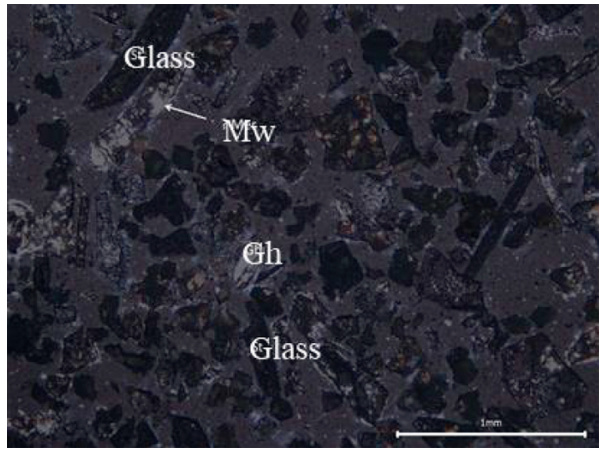

Figure 2: Microscopic image for GGBS.

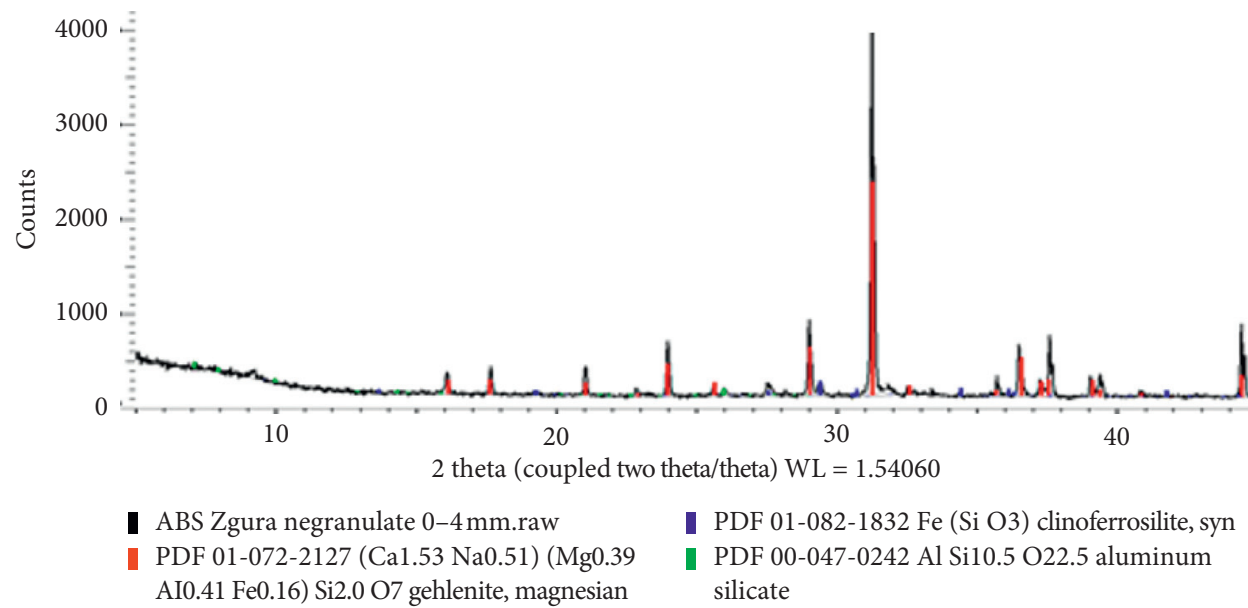

FIgURE 3: X-ray diffraction spectrum for ABS with characteristic lines for magnesian gehlenite, clinoferrosilite, and aluminium silicate. 


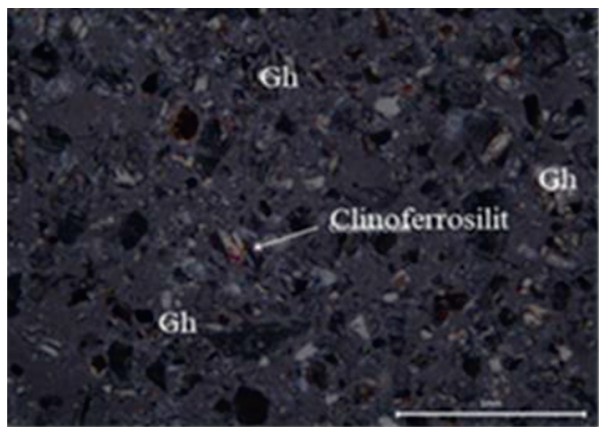

FIgURE 4: Microscopic image for ABS.

TABLe 1: Quantities for materials within mixtures.

\begin{tabular}{|c|c|c|c|c|c|}
\hline Quantities $\left(\mathrm{kg} / \mathrm{m}^{3}\right)$ & & & $\mathrm{DD}$ comp & & \\
\hline Raw materials & S 360 & S 414 & S $54 / 20$ & S $54 / 40$ & S $54 / 60$ \\
\hline Cement $(\mathrm{C})$ & 360 & 414 & 360 & 360 & 360 \\
\hline Blast furnace slag powder (GGBS) & - & - & 54 & 54 & 54 \\
\hline Total binder $(\mathrm{L})$ & 360 & 414 & 414 & 414 & 414 \\
\hline $\mathrm{W} / \mathrm{L}$ (water/binder) & 0.46 & 0.42 & 0.42 & 0.44 & 0.41 \\
\hline Natural sand (NA_0/4 mm) & 607 & 594 & 478 & 355 & 240 \\
\hline Blast furnace slag aggregate (ABS_0/4 mm) & - & - & 119 & 237 & 359 \\
\hline Coarse aggregate (CA_4/25 mm) & 1290 & 1261 & 1269 & 1256 & 1275 \\
\hline Density in fresh state & 2399 & 2434 & 2442 & 2435 & 2446 \\
\hline Superplasticizer additive & 3.60 & 4.14 & 4.39 & 4.55 & 4.97 \\
\hline Air entraining additive & 1.80 & 2.07 & 2.07 & 2.07 & 2.07 \\
\hline
\end{tabular}

\subsection{Methods}

\subsubsection{The Rapid Chloride Penetrability Test}

$R C P T$. For the RCPT test, cylindrical specimens with a diameter of $100 \mathrm{~mm}$ and a length of $200 \mathrm{~mm}$ were casted and covered with polyethylene foil, kept in the air for 24 hours at a temperature of $(20 \pm 2)^{\circ} \mathrm{C}$ and relative humidity of about $40 \%$, after which they were stripped and immersed in water at a temperature of $(20 \pm 2)^{\circ} \mathrm{C}$. The curing period of the test specimens in water was extended from 28 days to the test age of 150 days in order to observe the evolution of the durability characteristics of concrete (mechanical strength and resistance to chemical aggression) due to the continued hydration of slag particles over time. These characteristics are highlighted only after a longer curing period, such as at least 90 days. It is known that blast furnace slag is characterised by a slower hydration rate and a lower hydration heat compared to Portland cement [66-70]. Two days before the test, the $100 \mathrm{~mm}$ diameter cylindrical specimens were removed from the water, and a $50 \pm 3 \mathrm{~mm}$ thick strip from the top of the specimen was cut from each specimen to simulate the reinforcement coating. A water-impermeable epoxide was applied to the side of the specimens, and the upper and lower circular faces were left free. After drying the epoxy product, the specimens were kept in polyethylene foil until the start of the test to prevent evaporation of water. The preconditioning of the samples for the RCPT test was performed in a dry vacuum environment for $3 \mathrm{~h}$, after which the samples were covered with boiled water and cooled to room temperature. The container with the immersed samples was emptied, thus maintaining the samples for 20 hours for complete saturation. The preconditioning of the samples complied with the specifications of ASTM C1202 [35], except that the container was emptied with a standard apparatus in the absence of a vacuum saturator equipped with a desiccator, vacuum pump, and manometer. The electrical charges passed through the concrete sample for 6 hours, $Q$ (expressed in coulombs), was measured with the Controls device, model 58-E0052 to determine the capacity of the concrete in case of penetration of chloride ions, applying a potential difference of $60 \mathrm{~V}$ between the ends of the specimen (Figures 5 and 6). The ends of the sample were fixed in the two test cells after which the area between the sample and the test side in which electrolytic solutions were introduced was waterproofed, in one part sodium chloride solution, $\mathrm{NaCl}, 3 \%$, and in the other solution of $0.3 \%$ sodium hydroxide, $\mathrm{NaOH}$, in dilution with distilled water. The cell containing $3.0 \% \mathrm{NaCl}$ was connected to the negative pole (cathode); then, the cell containing $0.3 \% \mathrm{NaOH}$ was connected to the positive pole (anode). The air temperature around the samples was maintained in the range $(20 \pm 0.5)^{\circ} \mathrm{C}$, and the temperature sensor that monitored the solution was placed in the cell with sodium chloride. The standard ASTM C1202 [35] provides a correlation between the electrical charge passed at $6 \mathrm{~h}$ through a sample with a diameter of $95 \mathrm{~mm}$ and a thickness of $50 \mathrm{~mm}$ and between the penetrability of chloride ions, presented in Table 2 .

The evaluation of the resistance of concrete to the penetration of chloride ions determined by the ASTM C1202 


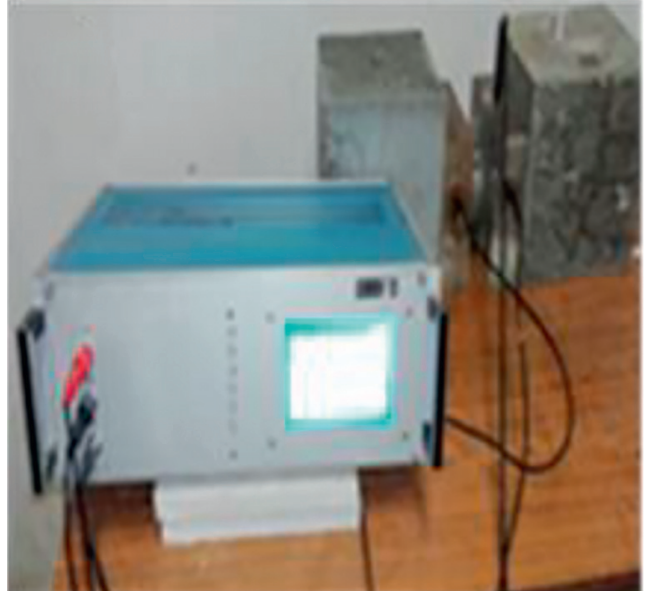

(a)

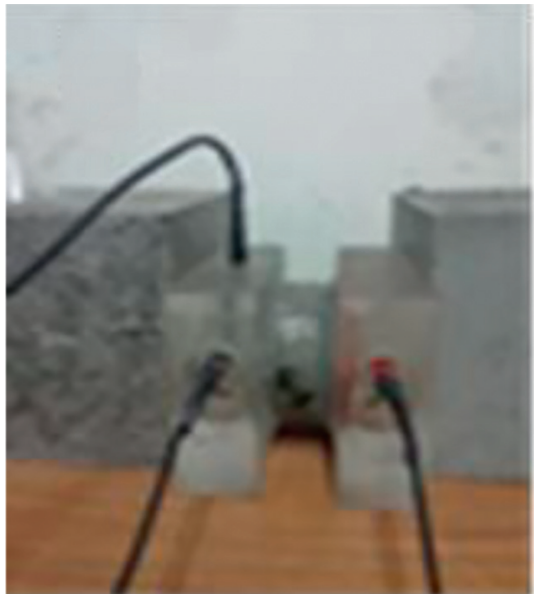

(b)

Figure 5: Specimen ready for test.

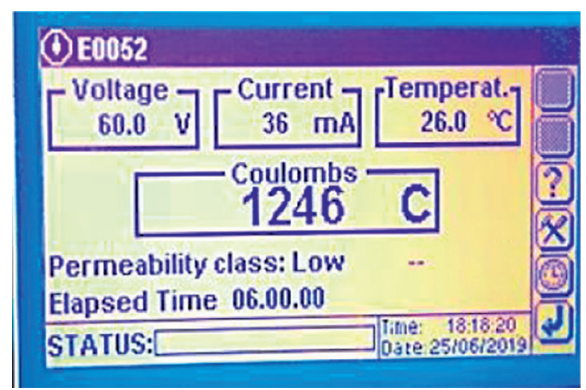

(a)

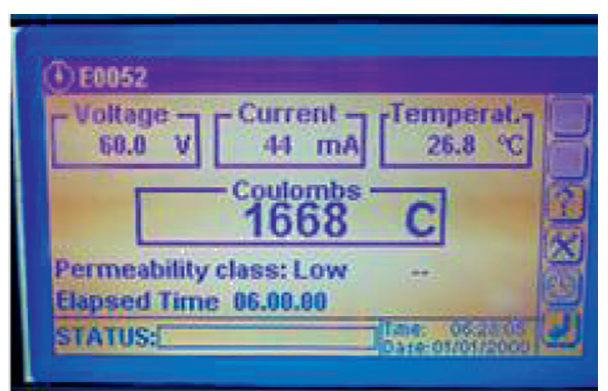

(b)

Figure 6: Recorded $Q$ at 6 h. (a) S 54/20 and (b) S 54/60.

TABLE 2: Results interpretation in compliance with [26].

\begin{tabular}{lc}
\hline Charge passed (coulombs) & Chloride ion penetrability \\
\hline$>4000$ & High \\
$2000-4000$ & Medium \\
$1000-2000$ & Low \\
$100-1000$ & Very low \\
$<100$ & Negligible \\
\hline
\end{tabular}

procedure can be sustained by determining the resistivity of the concrete. Julio-Betancourt and Hooton [71] recommended calculating the electrical resistivity of concrete 1 minute after the start of the test to avoid the influence of temperature on the mobility of chloride ions. Bassuoni et al. [1] noticed that at 30 minutes the maximum temperature gradient did not exceed $6^{\circ} \mathrm{C}$, resulting in comparable values of electrical resistivity. In this study, the temperature difference recorded from 1 minute to 30 minutes was up to $3^{\circ} \mathrm{C}$, which allowed the calculation of the resistivity of the concrete at $30 \mathrm{~min}$, as follows:

$$
\rho=\frac{V A}{I l},
$$

where $\rho=$ resistivity $(\Omega \mathrm{m})$ at 30 minutes, $V=$ applied voltage (V), $A=$ transversal area of the specimen $\left(\mathrm{m}^{2}\right), I=$ current intensity (A) at 30 minutes, and $L=$ thickness of the specimen (m).

The electric heating of the solution results in increased ion mobility in the pore solution. To avoid this effect, the passage of the electrical charges at $30 \mathrm{~min}$ was recorded and extrapolated linearly to estimate the passing charges at $6 \mathrm{~h}$. The electrical resistivity of the concrete was used to determine the corrosion rate of the reinforcement $\mathrm{Cr}(\mu \mathrm{m} \mathrm{Fe} / \mathrm{yr})$, calculated with equation (2) $[1,47,72]$ and classified as in Table $3[20,73]$.

$$
\mathrm{Cr}=\frac{1000}{\rho_{\text {concrete }}},
$$

where $\mathrm{Cr}=$ corrosion rate $(\mu \mathrm{m} \mathrm{Fe} / \mathrm{yr})$, ${ }^{\mathrm{a}}$ loss of reinforcement section from Faraday's law, $\rho_{\text {concrete }}=$ concrete resistivity $(\Omega \mathrm{m})$, and $\mathrm{LPR}=$ linear polarization resistance.

2.3.2. Determining the Chloride Ion Migration Coefficients (D) and the Depth of Penetration of the Chloride Ions. 
TABLe 3: Typical corrosion rates from LPR measurements.

\begin{tabular}{lc}
\hline Corrosion classification & $C_{r}(\mu \mathrm{m} \mathrm{Fe} / \text { year })^{\mathrm{a}}$ \\
\hline Passive/very low & $\mathrm{Up}$ to 2 \\
Low/mod & 2 to 6 \\
Mod/high & 6 to 12 \\
Very high & $>12$ \\
\hline
\end{tabular}

Immediately after the completion of the RCPT test, similarly to the tests performed by Bassuoni et al. [1] on the same samples, the migration coefficient of chloride ions was determined by colorimetric method, in compliance with the NT Build 492 Test [45]. The $50 \mathrm{~mm}$ thick concrete strips were split axially and sprayed with $0.1 \mathrm{~mol} / \mathrm{dm}^{3}(0.1 \mathrm{M})$ silver nitrate $\mathrm{AgNO}_{3}$ solution, forming a white precipitate of silver chloride on the surface of the specimen after 15 minutes. The white precipitation of silver nitrate was formed in the part of the face where chloride ions were present. The depth of chloride penetration $\left(x_{d}\right)$ for each sample is the average value of seven measurements made at different positions along the width of the sample. Chloride ion migration coefficients $(D)$ were calculated with the Nernst-Planck equation as follows:

$$
D=\frac{0.0239(273+T) L}{(V-2) t}\left(x_{d}-0.0238 \sqrt{\frac{(273+T) L x_{d}}{V-2}}\right),
$$

where $\quad D=$ non-steady-state migration coefficient $\left(\times 10^{-12} \mathrm{~m}^{2} / \mathrm{s}\right), V=$ applied voltage $(\mathrm{V}), T=$ average value of initial and final temperatures in the anolyte solution, $\mathrm{NaCl}$ $\left({ }^{\circ} \mathrm{C}\right)$, and $L=$ thickness of the specimen $(\mathrm{mm})$.

2.3.3. Determination of the Depth of the Carbonatation Layer of the Hardened Concrete. The depth of the carbonatation layer on the surface of the reinforced concrete was determined at the age of 28,56 , and 150 days, in compliance with the standard SR CR 12793:2002 [74], on fragments of prismatic specimens of $150 \times 300 \mathrm{~mm}$ (obtained from prisms with a length of $600 \mathrm{~mm}$ after the bending tensile test performed at the age of 28 days). Each of the two remaining fragments was used one for the carbonatation test and one for the 150-day compressive strength test. After the 28 days of hardening in water, the prism halves used for the carbonatation test were placed up to 150 days in the climatic chamber at a humidity of $(65 \pm 5) \%$, a temperature of $(20 \pm 2)^{\circ} \mathrm{C}$, and a normal carbon dioxide level. To check the ventilation of the air in the climate chamber, the average evaporation rate of water at 7 days from the free surface of a $30 \mathrm{~mm}$ glass was evaluated; the result was $44.59 \mathrm{~g}$. By the age of 56 days, the specimens were immersed in water for 6 hours after every 7 days, in accordance with the climatic conditions related to the exposure class (CX3) in an environment with alternating humidity-drying. The immersion in water for 6 hours was repeated before the test performed at the age of 150 days. At each test term, a strip of approximately $50 \mathrm{~mm}$ was made for each mixture and the solution of $1 \%$ phenolphthalein in $70 \%$ ethyl alcohol was sprayed on the freshly split face. The carbonatation depth $d_{k}$ $(\mathrm{mm})$ was determined by measuring the distance from the outer surface of the concrete to the edge of the red-purple coloured region.

2.3.4. Determining the Density, Water Absorption, and Absorption of the Pore Content of the Hardened Concrete

(1) Apparent Density on Specimens in Natural Humidity State. The cylindrical fragments remaining after cutting the cylindrical strips used in the RCPT test determined the density and content of permeable pores. The apparent density, $\rho_{a}$, at the age of 150 days was determined by measuring the volume of water displaced in cylindrical fragments with a diameter of $100 \mathrm{~mm}$ according to the reference method of EN 12390-7:2000 [75], respectively, as follows:

$$
\rho_{a}=\frac{m}{m_{a}-\left[\left(m_{s t}+m_{w}\right)-m_{s t}\right]},
$$

where $m=$ the mass of the specimen in natural humidity state $(\mathrm{g}) ; V_{a}=$ apparent volume of the specimen $\left(\mathrm{cm}^{3}\right)$; $m_{a}=$ mass of the specimen saturated measured in air (g); $m_{s t}=$ mass of the immersed caliper (g) (was 604 g), $m_{w}=$ mass of the saturated specimen, immersed in water (g); and $\rho_{\mathrm{w}}=$ water density, at $20^{\circ} \mathrm{C}$, with a calculus value of $1 \mathrm{~g} /$ $\mathrm{cm}^{3}$.

(2) Density after Immersion and Boiling, Water Absorption, and Absorption of Permeable Pore Content. For density after immersion and boiling, water absorption and permeable pore content were obtained according to ASTM C 642-2006 [76], a method also used in the study by MardaniAghabaglou et al. [77]. The ASTM C 642-2006 method allows the use of samples having a minimum volume of $350 \mathrm{~cm}^{3}$ or a specific weight of approximately $800 \mathrm{~g}$. The water-saturated specimens with the dry saturated surface were weighed in air (b) and then dried in an oven at $100-110^{\circ} \mathrm{C}$ until a constant mass (a) was reached. The specimens were placed in a container, covered with tap water, and boiled for 5 hours. They were then allowed to cool to room temperature $\left(22 \pm 2^{\circ} \mathrm{C}\right)$. The moisture from the surface was removed by swabbing with a towel and the dry mass on the surface of the immersed and boiled samples was determined (c); the mass was measured in air. The apparent mass (d) after immersion and boiling was measured in water with the hydrostatic balance. Absorption after immersion $\left(m_{1}\right)$ and absorption after immersion and boiling $\left(m_{2}\right)$ were calculated with the following equations:

$$
\begin{aligned}
& m_{1}=\left[\frac{(b-a)}{a}\right] \times 100(\%), \\
& m_{2}=\left[\frac{(c-a)}{a}\right] \times 100(\%) .
\end{aligned}
$$

The density in dry state $\rho_{1}$ and the density after saturation and boiling $\rho_{2}$ were calculated with the following equations: 


$$
\begin{aligned}
& \rho_{1}=\left[\frac{a}{c-d}\right] x \rho_{w}, \\
& \rho_{2}=\left[\frac{a}{a-d}\right] x \rho_{w},
\end{aligned}
$$

and for water density $\rho_{w}$ we used the value of $1 \mathrm{~g} / \mathrm{cm}^{3}$. The content of the permeable pores $\left(P_{0}\right)$ was calculated using the following equation:

$$
P_{0}=\left[\frac{c-a}{c-d}\right] \times 100
$$

in compliance with ASTM C 642-2006 [76].

The determination of the electric charge $(Q)$, the depth of penetration of chloride ions $\left(X_{d}\right)$, the migration coefficient of chloride ions $(D)$, and the content of permeable pores $\left(P_{0}\right)$ were determined from the average results of 3 cylindrical specimens with a diameter of $100 \mathrm{~mm}$ at the age of 150 days.

2.3.5. Determination of Compressive Strength at the Age of 150 days. The determination of the compressive strength, according to EN 12390-3:2002 [78], was performed on a prism fragment with a size of $150 \times 150 \times 300 \mathrm{~mm}$ resulting from the bending stress test at the age of 28 days. Preservation of the specimens was performed in the climatic chamber at temperatures of $(20 \pm 2)^{\circ} \mathrm{C}$ and relative humidity of $(65 \pm 5) \%$, until the age of 150 days.

\section{Results and Discussion}

3.1. Rapid Chloride Penetrability Test (RCPT). The electrical passing charges $(Q)$ after $6 \mathrm{~h}$, according to the RCPT rapid test, were in the range $(1255 \div 3089)^{\circ} \mathrm{C}$ and the extrapolated passing charges from the recordings at $30 \mathrm{~min}$ were between $(1262 \div 2798)^{\circ} \mathrm{C}$, which in in compliance with ASTM C1202. Table 2 corresponds to a low, respectively, moderate chloride ion penetrability class. The report between the recorded data sets and the extrapolated data sets, Figure 7 , is in the range $(0.80 \div 0.91)$; they are generally lower for the extrapolated values. The exception is the mixture $S$ 54/20 in which the ratio between extrapolated and recorded passages was 1.01 . This could indicate that for the mixture S 54/20 the effect of temperature on the passing charges had no influence. Table 4 shows the electrical resistivity at 30 minutes from the beginning of the RCPT test $(\rho)$, average temperature of the sodium chloride solution $\left(T_{\mathrm{med}}\right)$, depth of penetration of chloride ions $\left(X_{d}\right)$, nonequilibrium migration coefficient $(D)$, and corrosion rate $\left(C_{r}\right)$.

As seen in Figure 7, the electrical passing charges $(Q)$ for compositions with blast furnace slag are lower than those of the control composition S 414 made with conventional materials. This is attributed to the increased resistivity as shown in Table 4, respectively, to the reduction in electrical conductivity of the pore solution that could be induced by blast furnace slag powder, consistent with the results obtained in the study [1]. But of the blast furnace slag-free compositions, the lowest passing charges were recorded for $\mathrm{S}$ 414 which had a $w / c$ ratio of $(0.42)$, lower than those in the $S$ 360 mixture at which the $w / c$ ratio was 0.46 . This shows that an increased $w / c$ ratio can lead to a decrease in the resistivity of the concrete to the penetration of chloride ions. Figure 8 shows the evolution of the results for the corrosion rate. The lowest values of this indicator are observed in the mixtures $\mathrm{S}$ $54 / 20$ and $S$ 54/60.

3.2. Determining the Chloride Ions' Migration Coefficients (D) and the Depth of Penetration of Chloride Ions. The average penetration depth of chloride ions measured and the migration coefficients calculated according to equation (3) have values shown in Table 4. Figures 9 and 10 illustrate the chloride front for compositions S 360 and S 54/20, thus observing, visually, the depth of penetration of chloride ions into the concrete. Although these physical measurements are less dependent on the electrical conductivity of the concrete, the results have a common tendency with the results of the RCPT test. Thus, it was found that the average penetration depth of chloride ions of $5.20 \mathrm{~mm}$ registered in the composition S 54/20 and $9.43 \mathrm{~mm}$ in the composition S 54/60 resulted in migration coefficients $(D)$ with values of, respectively, 4.41 and $8.42 \times 10^{-12} \mathrm{~m}^{2} / \mathrm{s}$. These values were the lowest, similar to the results obtained after the rapid RCPT test.

3.3. Determination of the Depth of the Reinforced Concrete Carbonatation Layer. The carbonatation profile was determined using phenolphthalein as an indicator solution. One hour after spraying the surface, the noncarbonatated area will remain purple, with a $\mathrm{pH}$ higher than 9, while the carbonatated area will remain colourless, in compliance with SR CR 12793 [74]. From the visual analysis of the tested samples at the ages of 28,56 , and 150 days, it was found that all the tested samples did not lose their basicity, proved by maintaining the purple color on the entire sprayed surface. Figure 11 shows images with the appearance of the samples one hour after the application of the phenolphthalein solution compared to the freshly sprayed samples. Only a decrease in the intensity of the purple color is observed due to the drying of the solution on the sprayed surface. In this experiment, the depth of the carbonatation layer, $d_{k}$, was zero.

3.4. Determining Density, Water Absorption, and Impermeable Pores Content Absorption for Hardened Concrete. Following the determinations performed on fragments of cylinders with a side of $100 \mathrm{~mm}$, the content of permeable pores $\left(P_{0}\right)$, density in the dry state $\left(\rho_{1}\right)$, density after saturation and boiling $\left(\rho_{2}\right)$, apparent density in the state of natural humidity $\left(\rho_{a}\right)$, absorption after immersion $\left(m_{1}\right)$, and absorption after immersion and boiling $\left(m_{2}\right)$ were obtained, with results shown in Figures 12 and 13. The content of permeable pores, or the apparent porosity, was in this experiment a useful index of correlation of the pore structure with the migration coefficients of chloride ions in concrete, in accordance with the specifications in the specialty literature [1]. The values obtained for the apparent porosity are in the range $(5.63 \div 6.79) \%$, respectively, being lower than the limit 


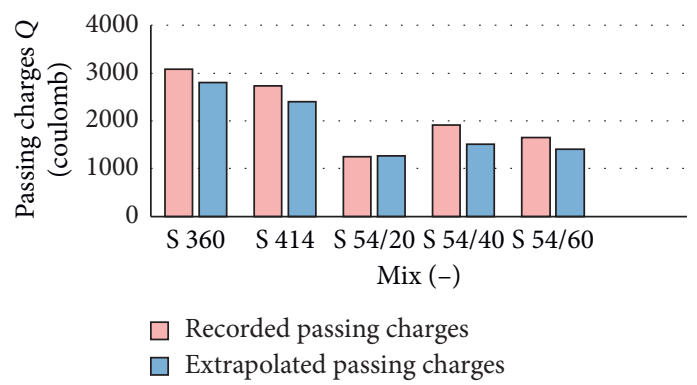

Figure 7: RCPT passing charges Q.

TABLE 4: Resistivity, chloride ions penetrability, and corrosion rate.

\begin{tabular}{lcccccc}
\hline Mixture & $\begin{array}{c}30 \text { min I current } \\
(\mathrm{mA})\end{array}$ & $\begin{array}{c}30 \text { min resistivity }(\Omega \\
\mathrm{m})\end{array}$ & $\begin{array}{c}T_{\text {med }} \\
\left({ }^{\circ} \mathrm{C}\right)\end{array}$ & $\begin{array}{c}X_{d} \text { penetration depth } \\
(\mathrm{mm})\end{array}$ & $\begin{array}{c}D \text { migration coefficient } \\
\left(\times 10^{-12} \mathrm{~m}^{2} / \mathrm{s}\right)\end{array}$ & $\begin{array}{c}\text { Cr }(\mu \mathrm{m} \mathrm{Fe} / \mathrm{yr} \\
\%)\end{array}$ \\
\hline S 360 & 130 & 72.73 & 27.63 & 33.53 & 32.32 & 22.16 \\
S 414 & 111 & 85.03 & 25.80 & 23.45 & 4.41 & $0.0137 \times 10^{-3}$ \\
S 54/20 & 58 & 161.58 & 23.43 & 5.20 & 12.96 & $0.0118 \times 10^{-3}$ \\
S 54/40 & 70 & 133.79 & 24.25 & 14.13 & 8.42 & $0.0075 \times 10^{-3}$ \\
S 54/60 & 65 & 144.17 & 23.73 & 9.43 & $0.0069 \times 10^{-3}$ \\
\hline
\end{tabular}

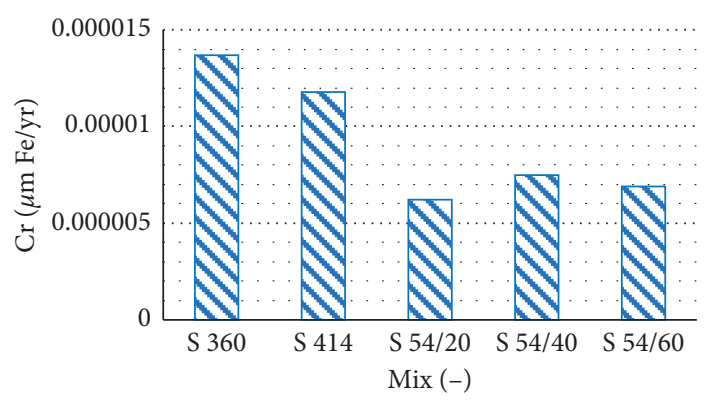

ه $\mathrm{Cr}(\mu \mathrm{m} \mathrm{Fe} / \mathrm{yr})$

Figure 8: Corrosion rate $\left(C_{r}\right)$.

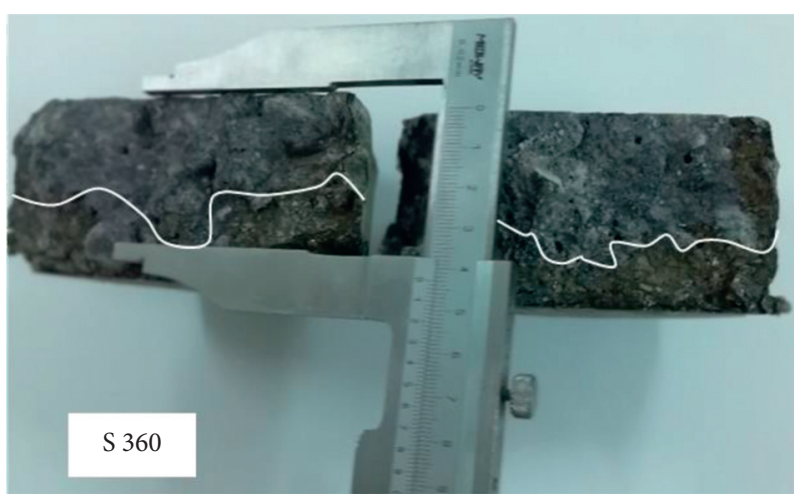

Figure 9: Chloride ions migration front for S 360.

of $10 \%$ above which the concrete is considered porous [79]. Gel pores $(\mathrm{CSH})$ were not monitored in this experiment because they do not have a major contribution in the transport mechanism of chloride ions in the concrete matrix, their role being the discontinuity of capillary pores [1]. These findings can be brought in line with the specifications in the specialty literature $[22,80]$. Thus, it is specified that the percentage of gel micropores $(<30 \mathrm{~nm})$ in slag concrete is 


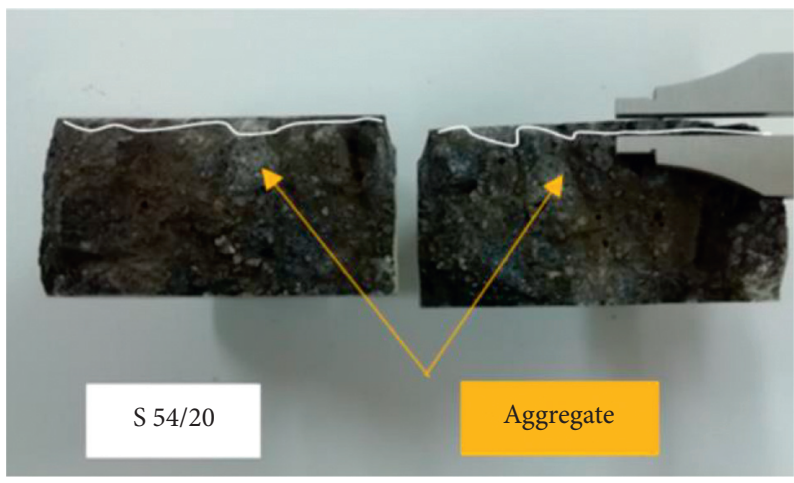

Figure 10: Chloride ions' migration front for S 54/20.

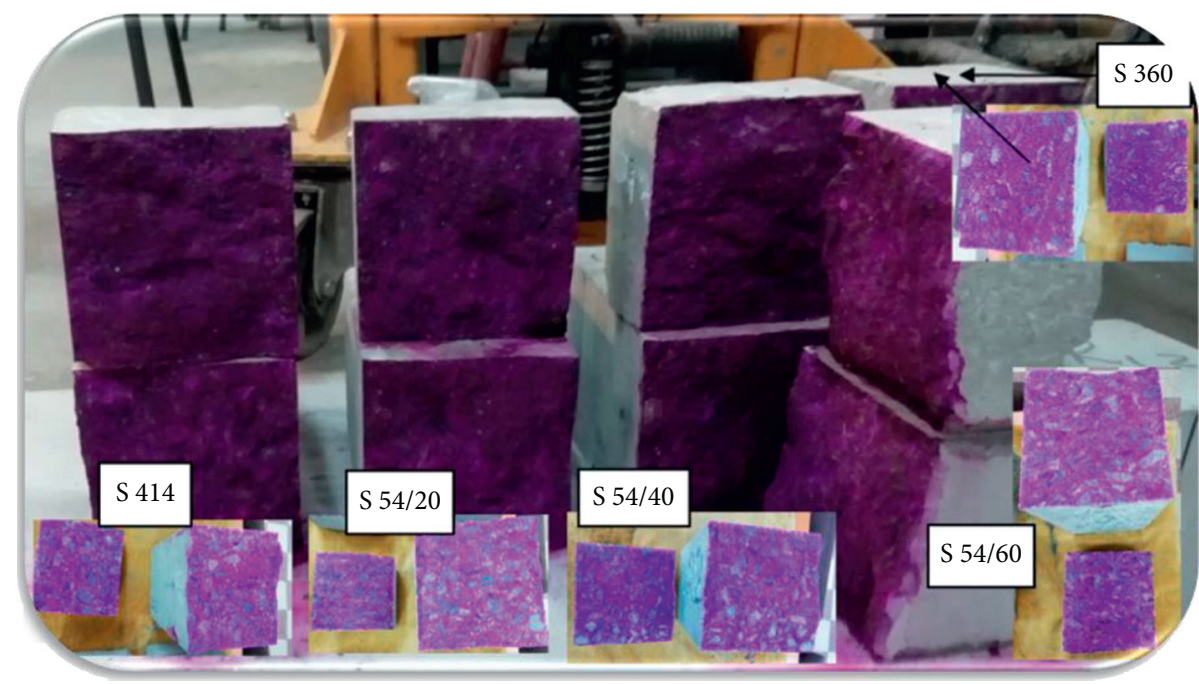

FIgURE 11: Carbonatation progress after 1 hour since the testing of the samples at the age of 56 days.

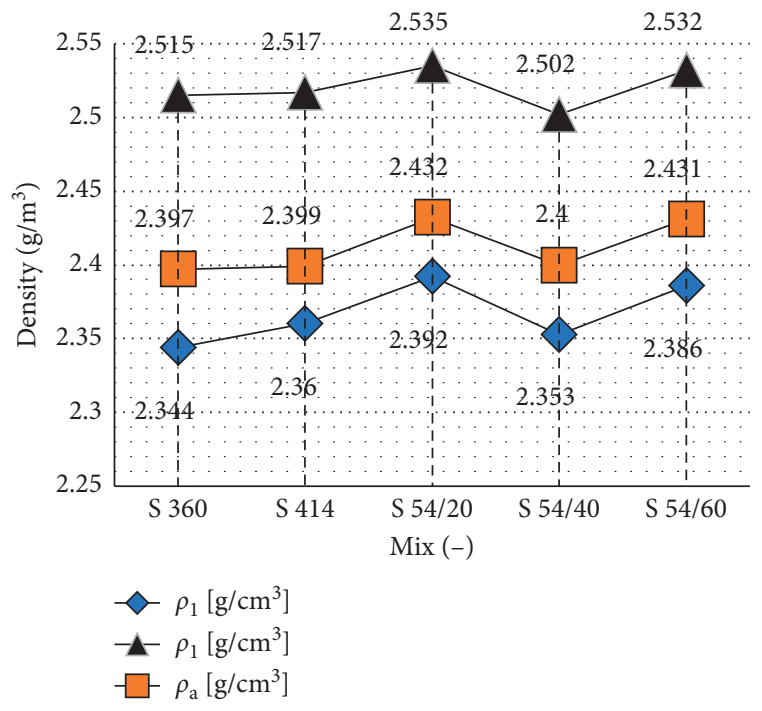

Figure 12: Density of mixtures $\left(\mathrm{g} / \mathrm{cm}^{3}\right)$. 


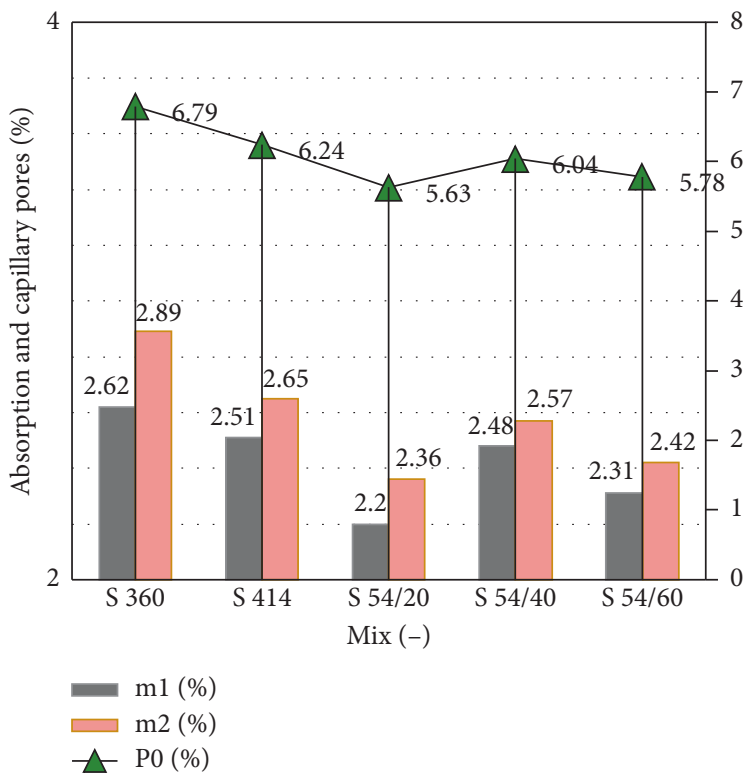

Figure 13: Water absorption and permeable pores' content (\%).

higher than that of Portland cement concrete, and the capillary porosity is lower. The cause of this difference, suggested by Bakker, is due to a different precipitation of the gel (CSH), which leads to a relative decrease in capillary porosity. The gel $(\mathrm{CSH})$ in the slag cement does not precipitate directly on the cement particles, but in the space between the granulation of the clinker particles and the blast furnace slag. This precipitation results in a better gel distribution (CSH), which leads to a lower diffusion and permeability of chloride ions to furnace slag concrete compared to Portland cement concrete $[22,81]$. Comparing the diagrams in Figures 12 and 13, it is observed that the apparent density of the mixtures has an inversely proportional evolution with the content of permeable pores, respectively, with the water absorption. Respectively, for compositions S 54/20 and S 54/60 with a lower content of permeable pores, the density of concrete is higher. The compositions S 414 and S 54/40 showed, respectively, a higher porosity and a lower density compared to the other compositions. For all three furnace slag compositions, the determined permeable pore content is lower compared to the control mixture S 414. The highest permeable pore content was recorded for the S 360 mixture. This was due the increased water/binder ratio $(0.46)$.

It is observed that the evolution of the permeable pore content (Figure 13) has the same upward trend with the migration coefficient of chloride ions (D) (Table 4). This indicates, similar to the specifications in the literature [1], a direct relationship between chloride migration coefficients and permeable pore content. The standard error of the estimate for $D$ is $2.02 \times 10^{-2} \mathrm{~m}^{2} / \mathrm{s}$, approximately $12.59 \%$ of the average value of the migration coefficients of $16.05 \times 10^{-2} \mathrm{~m}^{2} / \mathrm{s}$, as seen in Figure 14 .

As shown in the work of Jan [22], the high level of concrete quality is influenced by a low porosity, due to a lower content of capillary pores and a smaller network of interconnected pores. Such porosity was also recorded in mixtures S54/20 and S54/60, which led to a reduced transfer of chloride ions through the concrete matrix.

3.5. The Evolution of Mechanical Strength, Concrete Resistivity, and Depth of Penetration of Chlorine Ions in Concrete. As seen in Figure 15, the results of compressive strengths at the age of 150 days evolved similarly to those at the age of 28 days in the previous work of the authors [82]. Analyzing Figures 12 and 15, it results that the mechanical strengths at the age of 150 days are proportional to the values of the apparent density for all the mixing performed. The mechanical strengths of blast furnace slag mixtures were higher with values in the range $(0.63 \div 3.08) \%$ compared to the control mixture $S 414$, attributed to a higher compactness and a higher density, respectively. However, analyzing the evolution of the resistivity of concrete to the penetration of chlorine ions in Figure 16, increases between $(56.24 \div 88.69) \%$ are observed, with visibly higher values for blast furnace slag vs. (versus) control mixture S 414. The concentration of $3 \%$ sodium chloride (according to the RCPT rapid test) produced a lower impact on blast furnace slag mixtures, i.e., a lower content of free chlorine ions, which can be due to the increased chemical binding capacity of chlorine ions, a kinetic mechanism presented in the paper [52]. Further, in the diagram in Figure 16, the results obtained by the colorimetric method for the penetration depth of chlorine ions were completed. As expected, the depth of chlorine penetration into the concrete was inversely proportional to the resistivity and lower with values between $(39.74 \div 77.83) \%$ compared to the control mixture S 414 .

All these results led to eliminating uncertainties related to electrical loads registered in this study, using the rapid RCPT test. 


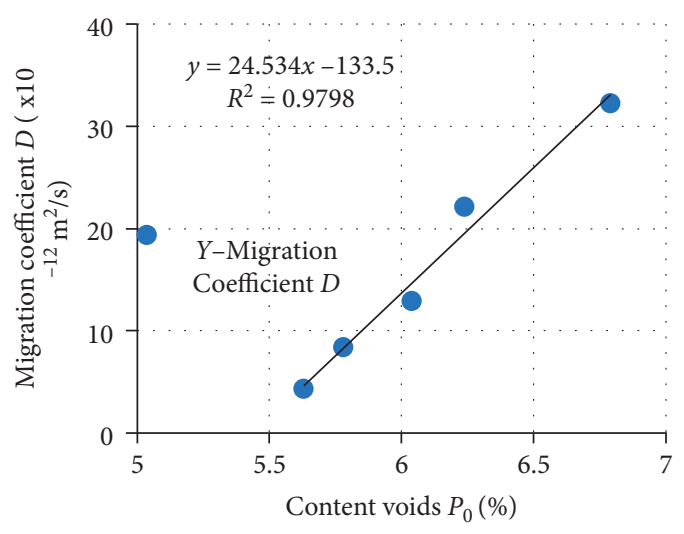

FIgURE 14: Relationship between $P_{0}(\%)$ and $D\left(\times 10^{-2} \mathrm{~m}^{2} / \mathrm{s}\right)$.

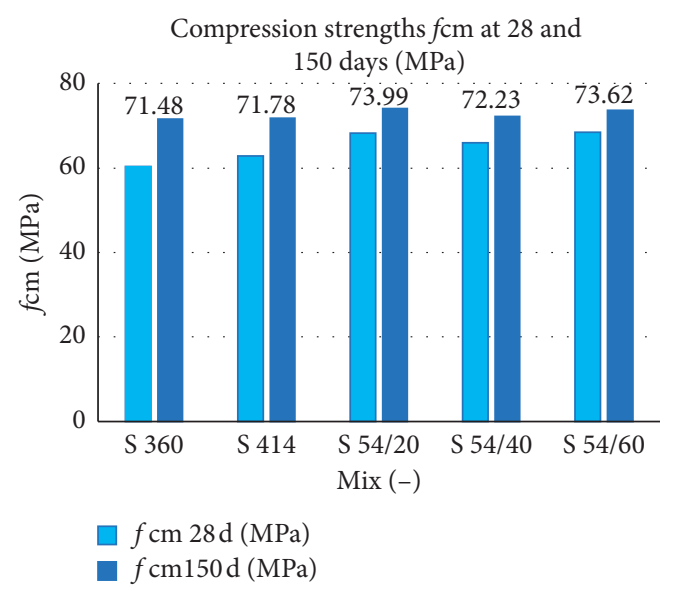

Figure 15: Compression strengths $f(\mathrm{~cm})$ at 28 and 150 days.

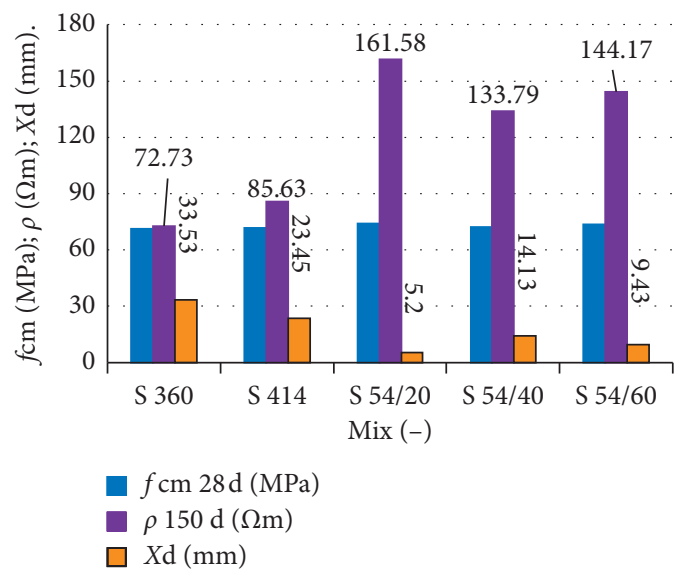

FIGURE 16: Comparation between compressive strength $(f(\mathrm{~cm}))$, concrete resistivity $(\rho)$ and penetration depth $\left(x_{d}\right)$ at 150 days.

\section{Conclusions}

The effect of blast furnace slag on the corrosion resistance of the reinforcement was studied by the RCPT rapid test according to the ASTM C1202 standard supplemented with the colorimetric method from the NT Build 492 test. These methods allowed the determination of the concrete resistivity and the corrosion propagation speed with the rapid RCPT test and identification of the depth of penetration and migration coefficients of chlorine ions by colorimetric method. The results were analysed and correlated with the porosity trends, with the depth of the carbonatation layer, with the compressive strengths, by comparison with the level of results obtained on the control mixture made with conventional materials. Based on the results of this study, the following conclusions can be presented:

(i) The electrical pass-through charges $(Q)$ obtained by the RCPT rapid test on slag compositions led to their classification in the low-penetrability class and for the control mixture in the moderatepenetrability class.

(ii) The corrosion rate calculated according to the resistivity of the concrete was below the value of $2 \mu \mathrm{m} /$ year for all the compositions made, thus determining the classification in the "very low" corrosion class, according to the classification in Table 3 of this article.

(iii) The temperature recorded in the sodium chloride solution used for the RCPT rapid test did not affect the electrical charges passed through the concrete samples, which confirms the validation of the test.

(iv) The high values of resistivity for mixtures with blast furnace slag content compared to the control ones, when chlorine ions penetrate, are due to the low concentration of sodium chloride (3\%) according to the RCPT rapid test and especially the presence of blast furnace slag in the mixture.

(v) Due to the lower apparent porosity of the slagcontaining concretes, the migration coefficients and the depth of penetration of chlorine ions in these compositions recorded lower values compared to the control mixture.

(vi) The penetrability of chlorine ions through concrete evaluated by the colorimetric method together with the results of the tested physical and mechanical characteristics supported the results obtained by the rapid RCPT test.

(vii) The depth of the carbonate layer was nonexistent, which reduced the risk of corrosion of the reinforcement in the mixtures, the result being attributed to increased compactness of the concrete matrix.

(viii) The results of this study indicate that the proportions of blast furnace slag in combination with the conventional materials used were the most effective for the S 54/20 and S 54/60 road concrete compositions.

\section{Data Availability}

The data sustaining the conclusions of this study are available within the tables and figures of the present paper. 


\section{Conflicts of Interest}

The authors declare that there are no conflicts of interest regarding the publication of this paper.

\section{Acknowledgments}

The authors would like to thank Lecturer Mr. Nicolae Har, Ph.D., from the Geology Department of the Babeş-Bolyai University, Cluj-Napoca, Romania, for his generosity toward research and supplying with the photographs taken at microscopic optic with polarized light and diffractometry with X-ray for granulated and nongranulated blast furnace slag.

\section{References}

[1] M. T. Bassuoni, M. L. Nehdi, and T. R. Greenough, "Enhancing the reliability of evaluating chloride ingress in concrete using the ASTM C 1202 rapid chloride penetrability test," Journal of ASTM International, vol. 3, no. 3, 2006.

[2] W. Scannell, A. Sohanghpurwala, and M. Islam, Assessment of Physical Condition of Concrete Bridge Components (FHWASA-97-002, HTA-10/1-96 (3M)P), U.S. Department of Transportation, Federal Highway Administration, Washington, DC, USA, 1996.

[3] A. Bentur, S. Diamond, and N. Berke, Steel Corrosion in Concrete, E \& FN SPON, London, UK, 1998.

[4] L. Bertolini, B. Elsener, P. Pedeferri, and R. Polder, Corrosion of Steel in Concrete, WILEY-VCH Verlag GmbH \& Co. KGaA, Weinheim, Germany, 2004.

[5] B. Pradhan and B. Bhattacharjee, "Rebar corrosion in chloride environment," Construction and Building Materials, vol. 25, no. 5, pp. 2565-2575, 2011.

[6] B. Elsener, "Macrocell corrosion of steel in concrete-implications for corrosion monitoring," Cement and Concrete Composites, vol. 24, no. 1, pp. 65-72, 2002.

[7] P. A. M. Basheer, P. R. V. Gilleece, A. E. Long, and W. J. Mc Carter, "Monitoring electrical resistance of concretes containing alternative cementitious materials to assess their resistance to chloride penetration," Cement and Concrete Composites, vol. 24, no. 5, pp. 437-449, 2002.

[8] J. N. Enevoldsen, C. M. Hansson, and B. B. Hope, "The influence of internal relative humidity on the rate of corrosion of steel embedded in concrete and mortar," Cement and Concrete Research, vol. 24, no. 7, pp. 1373-1382, 1994.

[9] O. Poupard, A. Aït-Mokhtar, and P. Dumargue, "Corrosion by chlorides in reinforced concrete: determination of chloride concentration threshold by impedance spectroscopy," Cement and Concrete Research, vol. 34, no. 6, pp. 991-1000, 2004.

[10] M. F. Montemor, M. P. Cunha, M. G. Ferreira, and A. M. Simões, "Corrosion behaviour of rebars in fly ash mortar exposed to carbon dioxide and chlorides," Cement and Concrete Composites, vol. 24, no. 1, pp. 45-53, 2002.

[11] C. L. Page and G. Sergi, "Developments in cathodic protection applied to reinforced concrete," Journal of Materials in Civil Engineering, vol. 12, no. 1, pp. 8-15, 2000.

[12] C. Andrade, C. Alonso, and J. Sarría, "Corrosion rate evolution in concrete structures exposed to the atmosphere," Cement and Concrete Composites, vol. 24, no. 1, pp. 55-64, 2002.

[13] G. Kim, J.-Y. Kim, K. E. Kurtis, L. J. Jacobs, Y. Le Pape, and M. Guimaraes, "Quantitative evaluation of carbonation in concrete using nonlinear ultrasound," Materials and Structures, vol. 49, no. 1-2, pp. 399-409, 2016.

[14] V. G. Papadakis, C. G. Vayenas, and M. N. Fardis, "Experimental investigation and mathematical modeling of the concrete carbonation problem," Chemical Engineering Science, vol. 46, no. 5-6, pp. 1333-1338, 1991.

[15] V. G. Papadakis, C. G. Vayenas, and M. N. Fardis, "Fundamental modeling and experimental investigation of concrete carbonation," ACI Materials Journal, vol. 88, pp. 363-373, 1991.

[16] L. J. Parrott and D. C. Killoh, "Carbonation in a 36 year old, in-situ concrete," Cement and Concrete Research, vol. 19, no. 4, pp. 649-656, 1989.

[17] R. A. Medeiros-Junior, M. G. Lima, R. Yazigi, H. Marcelo, and F. Medeiros, "Carbonation depth in 57 years old concrete structures," Steel and Composite Structures, vol. 19, no. 4, pp. 953-966, 2015.

[18] P. Pimienta, B. Albert, B. Huet, M. Dierkens, P. Fransisco, and P. Rougeau, "Durability performance assessment of nonstandard cementitious materials for buildings: a general method applied to the French context," RILEM Technical Letters, vol. 1, pp. 102-108, 2016.

[19] E. Namsone, G. Šahmenko, and A. Korjakins, "Durability properties of high performance foamed concrete," Procedia Engineering, vol. 172, pp. 760-767, 2017.

[20] L. Sadowski and M. Nikoo, "Corrosion current density prediction in reinforced concrete by imperialist competitive algorithm," Neural Computing and Applications, vol. 25, no. 7-8, pp. 16271638, 2014.

[21] K. Tuutti, Corrosion of Steel in Concrete, CBI Swedish Cement and Concrete Research Institute Stockholm Sweden, Stockholm, Sweden, 1982.

[22] B. Jan, Blast Furnace Slag Cement for Durable Marine Structures, Association of the Netherlands Cement Industry, Netherlands, 1998.

[23] E. M. Güneyisi, K. Mermerdaş, E. Güneyisi et al., "Numerical modeling of time to corrosion induced cover cracking in reinforced concrete using soft-computing based methods," Materials and Structures, vol. 48, no. 6, 2014.

[24] C. K. Nmai, S. A. Farrington, and G. S. Bobrowski, "Organicbased corrosion-inhibiting admixture for reinforced concrete," Concrete International, vol. 14, no. 4, pp. 45-51, 1992.

[25] N. Berke and A. Rosenberg, "Technical review of calcium nitrite corrosion inhibitor in concrete," Transportation Research Record Journal of the Transportation Research Board, vol. 1211, pp. 18-27, 1989.

[26] X. Pei, N. Martin, M. Green, A. Fam, and G. Shier, "Cementitious coatings for improved corrosion resistance of steel reinforcement," Surface \& Coatings Technology, vol. 315, pp. 188-195, 2017.

[27] K. Y. Yeau and E. K. Kim, "An experimental study on corrosion resistance of concrete with ground granulate blastfurnace slag," Cement and Concrete Research, vol. 35, no. 7, pp. 1391-1399, 2005.

[28] A. A. Ramezanianpour and V. M. Malhotra, "Effect of curing on the compressive strength, resistance to chloride-ion penetration and porosity of concretes incorporating slag, fly ash or silica fume," Cement and Concrete Composites, vol. 17, no. 2, pp. 125-133, 1995.

[29] G. J. Osborne, "Durability of portland blast-furnace slag cement concrete," Cement and Concrete Composites, vol. 21, pp. 11-21, 1999.

[30] E. F. Irassar, M. González, and V. Rahhal, "Sulphate resistance of type $\mathrm{V}$ cements with limestone filler and natural 
pozzolana," Cement and Concrete Composites, vol. 22, no. 5, pp. 361-368, 2000.

[31] K. M. A. Hossain and M. Lachemi, "Corrosion resistance and chloride diffusivity of volcanic ash blended cement mortar," Cement and Concrete Research, vol. 34, no. 4, pp. 695-702, 2004.

[32] O. E. Gjorv, "Effect of condensed silica fume on steel corrosion in concrete," ACI Materials Journal, vol. 92, no. 6, pp. 591-598, 1995.

[33] D. Whiting and W. Dziedzic, Resistance to Chloride Infiltration of Superplasticised Concrete as Compared with Currently Used Concrete Overlay Systems (FHWA/OH-89/009), U.S. Department of Transportation, Federal Highway Administration, Washington, DC, USA, 1989.

[34] D. Whiting, "Rapid measurement of the chloride permeability of concrete," Public Roads, vol. 45, no. 3, pp. 101-112, 1981.

[35] ASTM C 1202, Electrical Indication of Concrete's Ability to Resist Chloride Ion Penetration, Annual Book of American Society for Testing Materials, Philadelphia, PA, USA, 2000.

[36] R. D. Hooton, P. Pun, T. Kojuncdic, and P. Fidjestol, "Influence of silica fume on chloride resistance of concrete," in Proceedings of PCI/FHWA International Symposium on High Performance Concrete, pp. 245-256, New Orleans, LA, USA, 1997.

[37] https://www.betonconsultingeng.com/services/concrete-testing/ astm-c1202/.

[38] C. Andrade and C. Alonso, "Test methods for on-site corrosion rate measurement of steel reinforcement in concrete by means of the polarization resistance method," Materials and Structures, vol. 37, no. 9, pp. 623-643, 2004.

[39] C. Alonso, C. Andrade, and J. A. González, "Relation between resistivity and corrosion rate of reinforcements in carbonated mortar made with several cement types," Cement and Concrete Research, vol. 18, no. 5, pp. 687-698, 1988.

[40] B. B. Hope, A. K. Ip, and D. G. Manning, "Corrosion and electrical impedance in concrete," Cement and Concrete Research, vol. 15, no. 3, pp. 525-534, 1985.

[41] L. Sadowski, "Methodology for assessing the probability of corrosion in concrete structures on the basis of half-cell potential and concrete resistivity measurements," The ScientificWorld Journal, vol. 2013, Article ID 714501, 8 pages, 2013.

[42] S. Feliu, J. A. Gonzalez, S. Feliu, and M. C. Andrade, "Confinement of the electrical signal for in situ measurement of polarization resistance in reinforced concrete," ACI Materials Journal, vol. 87, no. 5, pp. 457-460, 1990.

[43] G. K. Glass, C. L. Page, and N. R. Short, "Factors affecting the corrosion rate of steel in carbonated mortars," Corrosion Science, vol. 32, no. 12, pp. 1283-1294, 1991.

[44] W. López, J. A. González, and C. Andrade, "Influence of temperature on the service life of rebars," Cement and Concrete Research, vol. 23, no. 5, pp. 1130-1140, 1993.

[45] NT BUILD 492, Chloride Migration Coefficient from Nonsteady-State Migration Experiments, NORDTEST, Finland, 1999.

[46] https://www.betonconsultingeng.com/services/concrete-testing/ nt-build-492/.

[47] R. B. Polder, "The influence of blast furnace slag, fly ash, and silica fume on corrosion of reinforced concrete in marine environment," Heron, vol. 41, no. 4, pp. 287-300, 1996.

[48] P. F. McGrath and R. D. Hooton, "Influence of voltage on chloride diffusion coefficients from chloride migration tests," Cement and Concrete Research, vol. 26, no. 8, pp. 1239-1244, 1996.
[49] H. R. Soleymani and M. E. Ismail, "Comparing corrosion measurement methods to assess the corrosion activity of laboratory OPC and HPC concrete specimens," Cement and Concrete Research, vol. 34, pp. 2037-2044, 2004.

[50] A. Coşa, F. Popa, C. Negruțiu, and Z. Kiss, "The chloride penetration depth of self-compacting concrete using scanning electron microscopy," Acta Technica Napocensis: Civil Engineering \& Archiecture, vol. 62, no. 2, pp. 44-53, 2019.

[51] P. Sancharoen and T. Uomoto, "Corrosion of reinforcing steel in GGBS concrete due to cyclic exposure of chloride and carbonation," in Proceedings of the Annual Convention of Japan Concrete Institute, Kochi, Japan, 2004.

[52] A. Noushini, A. Castel, J. Aldred, and A. Rawal, "Chloride diffusion resistance and chloride binding capacity of fly ashbased geopolymer concrete," Cement and Concrete Composites, vol. 105, 2020.

[53] M. Á. Sanjuán, C. Andrade, P. Mora, and A. Zaragoza, "Carbon dioxide uptake by cement-based materials: a Spanish case study," Applied Sciences, vol. 10, no. 1, p. 339, 2020.

[54] C. Remus, "Experimental determinations regarding the reuse of concrete resulting from the demolition of buildings," 2017, http://www.upt.ro/img/files/20162017/doctorat/teze/ rezumat/Chendes_Remus_rezumatul_tezei_ro.pdf.

[55] R. Bleishwitz and B. Bahn-Walkowiak, "Aggregates and construction markets in Europe: towards a sectorial action plan an sustainable resource management," Minerals Engineering, vol. 22, no. 3, pp. 159-176, 2007.

[56] EN 197/1, Standard Cement- Part 1: Composition, Specification, and Conformity Cririteria Common Cements, European Committee for Standardization, Brussels, Belgium, 2011.

[57] EN 15167/1, Standard Ground Granulated Blast Furnace Slag for Use in Concrete, Mortar and Grout Part 1: Definitions, Specifications and Conformity Criteria, European Committee for Standardization, Brussels, Belgium, 2007.

[58] M. Kosior-Kazberuk, "Surface scaling resistance of concrete with fly ash from Co-combustion of coal and biomass," Procedia Engineering, vol. 57, pp. 605-613, 2013.

[59] V. G. Papadakis and S. Tsimas, "Supplementary cementing materials in concrete," Cement and Concrete Research, vol. 32, no. 10, pp. 1525-1532, 2002.

[60] T. Sinsiri, W. Kroehong, C. Jaturapitakkul, and P. Chindaprasirt, "Assessing the effect of biomass ashes with different finenesses on the compressive strength of blended cement paste," Materials \& Design, vol. 42, pp. 424-433, 2012.

[61] NE 014, The Norm for the Execution of Cement Concrete Road Pavements in a Fixed and Sliding Formwork System, Matrix Rom, Bucharest, Romania, 2002.

[62] European Committee for Standardization, "EN 12620: and EN 12620+A1: 2008, aggregates for concrete," European Committee for Standardization, Brussels, Belgium, 2003.

[63] EN 1008, Standard for Mixing Water for Concrete, European Committee for Standardization, Brussels, Belgium, 2003.

[64] EN 206+A. 1:2017, Standard for Concrete-Part 1: Specification, Performance, Production and Conformity, European Committee for Standardization, Brussels, Belgium, 2002.

[65] NE 012-1, Code of Practice for the Manufacturing of Concrete, Matrix Rom, Bucharest, Romania, 2007.

[66] A. Król, Z. Giergiczny, and J. Kuterasińska-Warwas, "Properties of concrete made with low-emission cements CEM II/ C-M and CEM VI," Materials, vol. 13, no. 10, p. 2257, 2020.

[67] Z. Giergiczny, "Fly ash and slag," Cement and Concrete Research, vol. 124, pp. 487-495, 2019.

[68] A. Król, "The role of the granulated blast furnace slag in sustainable cement production and waste management," 
Economic and Environmental Studies, vol. 17, no. 43, pp. 613-624, 2017.

[69] A. Król, "The role of the silica fly ash in sustainable waste management," in Proceedings of the E3SWeb of Conferences, 1st International Conference on the Sustainable Energy and Environment Development (SEED), vol. 10, Cracow, Poland, May 2016.

[70] M. I. Khan and C. J. Lynsdale, "Strength, permeability, and carbonation of high-performance concrete," Cement and Concrete Research, vol. 32, no. 1, pp. 123-131, 2002.

[71] G. A. Julio-Betancourt and R. D. Hooton, "Study of the joule effect on rapid chloride permeability values and evaluation of related electrical properties of concrete," Cem. Concr. Res., vol. 34, no. 6, pp. 1007-1015, 2004.

[72] W. Lopez and J. A. Gonzalez, "Influence of the degree of pore saturation on the resistivity of concrete and the corrosion rate of steel reinforcement," Cement and Concrete Research, vol. 23, no. 2, pp. 368-376, 1993.

[73] S. Millard, Measuring the Corrosion Rate of Reinforced Concrete Using Linear Polarisation Resistance, DTI DME Consortium, Good Practice Guide No 132, Liverpool, UK, 2003.

[74] SR CR 12793, Measurement of the Carbonation Depth of Hardened Concrete, European Committee for Standardisation, Brussels, Belgium, 2002.

[75] EN 12390-7, Testing Hardened Concrete -Part7: Density of Hardened Concrete, European Committee for Standardisation, Brussels, Belgium, 2002.

[76] ASTM C 642, Standard Test Method for Density, Absorption and Voids in Hardened Concrete, ASTM International, West Conshohocken, PA, USA, 2006.

[77] A. Mardani-Aghabaglou, Ö. Andiç-Çakir, and K. Ramyar, "Freeze-thaw resistance and transport properties of highvolume fly ash roller compacted concrete designed by maximum density method," Cement and Concrete Composites, vol. 37, pp. 259-266, 2013.

[78] EN 12390-3, Testing Hardened Concrete-Compressive Strength of Test Specimens, European Committee for Standardisation, Brussels, Belgium, 2002.

[79] A. M. Neville, Properties of Concrete, Bucharest Technical Publishing House, Bucharest, Romania, 1979.

[80] H. Romberg, "Cement paste pores and concrete properties (Zementsteinporen und Betoneigenschaften)," Beton-Informationen, vol. 18 , no. 5, pp. 50-55, 1978.

[81] R. R. M. Bakker, Permeability of Blended Cement Concretes, Paper SP79-30 from ACI SP79, ACI Committee, Detroit, MI, USA, 1983.

[82] L. M. Nicula, O. Corbu, M. Iliescu, and D. G. Dumitraş, "Using the blast furnace slag as alternative source in mixtures for the road concrete for a more sustainable and a cleaner environment," Romanian Journal of Materials, vol. 50, no. 2, pp. 224-231, 2020. 